\title{
On the sources and transmission of the Early Vannetais noëls
}

Sources et transmission des Anciens noëls vannetais

\section{Anders Richardt Jørgensen}

\section{(2) OpenEdition \\ 1 Journals}

Electronic version

URL: https://journals.openedition.org/lbl/2007

DOI: $10.4000 / \mathrm{lbl} .2007$

ISSN: 2727-9383

\section{Publisher}

Université de Bretagne Occidentale - UBO

\section{Printed version}

Date of publication: 1 February 2013

Number of pages: 203-231

ISBN: $979-10-92331-00-4$

ISSN: $1270-2412$

\section{Electronic reference}

Anders Richardt Jørgensen, "On the sources and transmission of the Early Vannetais noëls", La Bretagne Linguistique [Online], 17 | 2013, Online since 01 May 2021, connection on 22 May 2021. URL: http://journals.openedition.org//bl/2007 ; DOl: https://doi.org/10.4000//bl.2007

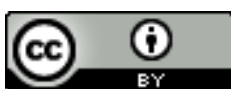

La Bretagne Linguistique est mise à disposition selon les termes de la Licence Creative Commons Attribution 4.0 International. 


\title{
On the sources and transmission of the Early Vannetais noëls
}

\begin{abstract}
$\mathrm{I}_{\mathrm{n}}$ noëls ${ }^{1}$ (henceforth referred to as the NG following GIB). The noëls in the NG are important above all because they represent the earliest specimen of Vannetais Breton of more than a few lines, rivalled only by the much shorter 1631 Prône (edited by Ernault 1905a and Loth 1905). The present study does not pretend to be a thorough investigation of the NG, but merely a collection of notes that will hopefully shed new light on the nature of the NG and its sources.
\end{abstract}

\section{Previous work on the NG}

The manuscript, which has lost both its beginning and its end, contains 17 noëls, numbered 7 to 22 by the scribe. The beginning of the first noël (number 6) and the end of the last (number 22) are missing due to loss of pages. The first preserved noël (number 6, on

* Uppsala University

1. I use the French term noël instead of the English Christmas Carol (or Christmas Hymn). This is because the French noël (and the Early Breton nouel for that matter) does not exclusively deal with the events surrounding Christmas, but may cover a wider range of themes. 
The Final Judgement) was edited by Ernault (1905b) shortly after the discovery of the manuscript. Later, the noëls were edited in full by Roparz Hemon, under the title Christmas Hymns in the Vannes dialect of Breton (Hemon 1956). I have used this edition as the foundation for the present work. According to Hemon, the manuscript was dated on the basis of its physical appearance to about 1680, but the high proportion of internal rhyme in some noëls led Hemon to suggest a date of composition in the first half of the 17th century (Hemon 1956: xi). The reasoning behind this is not evident, since, considering the varied nature of the noëls in the NG, all need not have been composed at the same time. We shall return to this question in $\S 6$.

Hemon (1956: 1xx-lxxi) furthermore divided the noëls into three classes (I-III) on the basis of the percentage of internal rhyme, class I being essentially "new versions of older [Middle Breton] hymns", class III being "probably more recent in origin", with class II occupying an intermediate position. While this for the most part provides a useful classification of the individual noëls, some of the conclusions drawn by Hemon on the basis of internal rhyme will have to be modified in light of the evidence presented below.

\section{The word grieff 'grievous, grave'}

The first point to be made concerns the peculiar word $<$ grieff $>$. This word occurs a total of four times in the NG: three times in noël 16 and once in noël 19. It is taken by Hemon (1956: 111; followed by Le Menn 1998a: 178) to be a variant of the much better attested Middle Breton word gref 'grave, sorrowful; grief' (from Old or Middle French grief). ${ }^{2}$ It should be noted, however, that the variant with $<$ ie $>$ is otherwise exceedingly rare in Breton. The only attestations known to me of the variant with $<\mathrm{ie}>$ outside the NG occur in the prose section of the Tragedien Sacr (TS, $1651^{3}$ ) and in the Doctrinal (Dnal., mid-17th century, printed in $1689^{4}$ ). In both these instances, the context clearly shows that it means 'grave, heavy', possibly being

2. Cf. Catholicon nebeut gref "vng pou grief".

3. TS (ed. LE MENN 1998a) 4/1: ma pechedou ... a so quen grief, hac en quer bras nombr.

4. Dnal. (1689 edition) 132: Arre [...] à recevé ar Badiziant dre feintise dre aon, pe dre avariç [...] à pec h griefamant. 
nonce-borrowings from French. This casts doubt on the identification of NG grieff as the rare Breton word grief since, as we shall see, the two words do not occur in the same context. Therefore we shall have a fresh look at the attestations of grieff in the NG.

\subsection{Noël 19 (no rhyme, disyllabic)}

In the single attestation in noël 19 we find en tan grieff, translated by Hemon as "in grievous fire".

\begin{tabular}{|c|c|c|}
\hline \multicolumn{2}{|c|}{ NG 19, I. 1610-1611 (Hemon 1956: 85) } & Translation (by Hemon, here and elsewhere) \\
\hline 2.7 & Na vemp en tan grieff & That we should not be in grievous fire \\
\hline 2.8 & I-n iffernë berhuiquIN. & In Hell forever \\
\hline
\end{tabular}

As can be seen, grieff must be read as disyllabic to make the required six syllables per line. It does not enter into rhyme, being in an odd-numbered line, which are exempt from rhyme in noël 19. The attestation is accordingly relatively straightforward.

\subsection{Noël 16 (no rhyme, disyllabic)}

The second attestation, I- $n$ tan grieff, is very similar. It is translated by Hemon as "into the grievous fire".

\begin{tabular}{|l|l|l|}
\hline \multicolumn{2}{|l|}{ NG 16, I. 1099-1102 (Hemon 1956: 58) } & Translation \\
\hline 4.5 & Ac en deur e vesaint & From the water they shall be \\
4.6 & I-n tan grieff taulET, & Thrown into the grievous fire, \\
4.7 & Beruet i-n iffernë iain. & Boiled in cold Hell. \\
4.8 & Allas, pebes pennET! & Alas, what punishment ! \\
\hline
\end{tabular}

We may once again note that grieff is disyllabic and that it does not enter into rhyme.

\subsection{Noël 16 (apparent rhyme with irder, disyllabic)}

Once again, we find $e-n$ tan grieff, translated by Hemon as "in grievous fire". 


\begin{tabular}{|l|l|l|}
\hline NG 16, I. 1234-1237 (Hemon 1956: 64) & Translation \\
\hline 21.5 & E vezaint puniset, & They shall be punished, \\
21.6 & Losquet e-n tan grieFF & Burned in grievous fire \\
21.7 & Gant er hy Luciffer, & By the cur Lucifer, \\
21.8 & En pouen hac en irdER. & In pain and longing \\
\hline
\end{tabular}

As in the preceding attestations, grieff is disyllabic. However, in this attestation it looks as if grieff ought to rhyme with en irder. The easiest way to achieve a regular rhyme is to assume that the line order has been reversed between the seventh and the eighth line. If we assume this, we obtain a regular rhyme between Luciffer and en irder:

\begin{tabular}{|l|l|l|}
\hline 21.5 & E vezaint puniset, & They shall be punished \\
21.7 & Gant er hy LuciffER, & By the cur Lucifer, \\
21.6 & Losquet e-n tan grieff & Burned in grievous fire, \\
21.8 & En pouen hac en irdER. & In pain and longing \\
\hline
\end{tabular}

\subsection{Noël 16 (apparent rhyme with baradoes, disyllabic)}

Once again, we find $e-n$ tan grieff, translated by Hemon as "in grievous fire".

\begin{tabular}{|l|l|l|}
\hline NG 16, I. 1087-1090 (Hemon 1956: 58) & Translation \\
\hline 3.1 & Dannet oemp e-n Iffernë, & We were damned in Hell, \\
3.2 & Dannet e-n tan griEFF, & Damned in grievous fire \\
3.3 & Ha colet dimp hon lot & And had lost our share \\
3.4 & A-ues er baradoES & Of Paradise \\
\hline
\end{tabular}

As before, grieff is disyllabic, but in this position, line-final in an even-numbered line, it ought to participate in the end-rhyme. Therefore we expect grieff to rhyme with baradoes 'Paradise'. Reordering the lines, as in $\S 2.3$, will not help and consequently we appear to be faced with a rhyme grieff = baradoes. While there is always the possibility that the rhyme is missing due to corruption in the course of transmission or that the stanza was simply imperfect to begin with, we shall nevertheless keep the apparent rhyme grieff = baradoes in mind as we proceed. 


\subsection{Grievous fire?}

It is in itself suspicious that a word as rare as grieff should occur a total of four times in the NG. As mentioned earlier, it barely appears to be attested outside the NG, occurring only in the TS and the Dnal. (where it clearly means 'grave', 'gravely'). We may also note that all four times it occurs in the NG, it qualifies the noun tan, used about the fire of Hell. So while "grievous fire" (as Hemon translates it) is certainly not impossible, it is not exactly self-evident either. In light of this and the rhyme grieff = baradoes (cf. $\S 2.4$ above), I will now suggest an alternative analysis: the adjective grieff, used to describe the fire of Hell, is in reality nothing more than a miscopying of a word * gries, cognate with MBret. grizias, ${ }^{5}$ EModBret. grizyes, gries, meaning 'burning (painfully)'.

\subsection{Early Modern Breton gri(zy)es}

The word grizyas, grizyes, gries 'burning' is well known from the religious literature. A few attestations will show its use (cf. GIB ${ }^{2}$ 1056):

M 2415: Ha tan grizias hastiff ouz ho lesquiff dimat

Cantiquou Spirituel ... (anonymous, 1642; ed. Le Menn 1997), 105: Diouz an tan gries.

Canticou spirituel... (Maunoir, Quimper, 1646), 129: Da veza dre ho trugarez / Tenned ouz an flammou griez. 145: Gant an douar e vezint lonquet, / Ha dan flammou gries taulet.

An Templ consacret... (Maunoir, Quimper 1679), 147: Penaus e hillite enduri / En Infern ar flammou grizies, / Pere abado da iames.

Canticou Spirituel var an oll exercicou... ([Le Bris], Morlaix, 1698), 39: Da vïana ho pet trüez / Ouc'h ho phoanyou en tan grizyes; 110: Allas coll ar Barados ha beza da james / Gãt an Diaoul o tevi e creis an tan grizyes; 331: Rac-se na bermetit james, / E couezzen er flammou grizyes / A so preparet en Ifern / Da zevi enno birviquen; 331: Ha pa ho pezo coundaonet / Dan tan grizyes ar Re gollet.

Tragedi ar hiniveles En Brez[onec] (= early 19th c.(?) Trég. ms. copy of the "Pastoral var Guinivelez Jesus-Christ"; ed. Hamilton 1976, 1984), 60: ma breman evi a james / condaonet dan tourmancho gries.

5. It is unclear why we sometimes find grizyas and sometimes grizyes. 
As can be seen from the examples, Middle and Early Modern Breton grizias, grizyes, gries is typically used to describe the tan 'fire' or flammou 'flames' of Hell, ${ }^{6}$ making it a perfect match for tan grieff in the NG.

If the identification of grieff in the NG with EModBret. gries, grizyes 'burning, scorching' is correct, as I believe it is, it most likely tells us that the form grieff came about through a trivial miscopying of "long s", $<\boldsymbol{\beta}$, as $<\mathrm{f}>$. Since the miscopying is consistent, it is likely that the copyist was completely unfamiliar with the word gries 'burning' in his exemplar. In this connection, it is interesting to note that gries, the expected KTV outcome of MBret. * ${ }^{\text {grizyes } / \text { griojes/, }}{ }^{7}$ has never been securely attested in Vannetais. This may explain the ignorance of the scribe. It also makes it likely that the noëls containing grieff (noël 16 and 19) were originally written in a nonVannetais dialect, specifically Cornouaillais or Trégorrois (the $-z-/ \delta /$ would not have been lost in Standard Middle Breton and Léonais). Alternatively, the word may still have been current in the variety of Vannetais used by the author(s) of noël 16 and 19, but may have been unknown to a later copyist.

\section{The NG noëls in the Breton tradition}

Having now uncovered a small part of the prehistory of the NG, the possibly dialectally motivated miscopying of * gries 'burning' as grieff, we may look beyond the manuscript text for more information. Specifically we may try to identify parallel versions of the noëls from other sources. A search through the various collections

6. We also find the word in a more mundane context outside the religious literature: guin grizyas 'vinum asperum; vin rude' (Nom. 64) and lynaden grizyas 'ortie griesche; stinging nettle' (Col.a.4: II.98).

7. The medial $<\mathrm{z}>$ represents old $/ \delta /$ as shown by its occasional loss in the Cantiquou spirituel and in Maunoir's writings (probably showing Cornouaillais influence). The etymology is not entirely settled (cf. LE MENN 1997: 409 for references to previous proposals), but most likely grizyes is a borrowing from OFr. gregeis, grezeis, grezois 'Greek'. The meaning of the Breton word seems to have been abstracted from OFr. feu grezeis 'Greek fire; incendiary weapon originally used by the Byzantine Empire' (= Bret. tan grizyes) and ortie gregeise 'stinging nettle', lit. 'Greek nettle' (= Bret. lynaden grizyas). The phonological details remain to be worked out, however. 
of popular songs from the Vannetais area ${ }^{8}$ and elsewhere ${ }^{9}$ and the modern printed collections of canticles has come up empty so far, but in one of the oldest collections of Vannetais canticles at least two of the noëls known from the NG reappear.

\section{Noëls in the Cantikeu}

The relevant collection of canticles, likely dating from 1760 or shortly thereafter, is entitled:

"CANTIKEU / SPIRITUEL, / PÉ / GUERZENNEU / DEVOTT / HA FORH-POURFITAB, / Composed à nehué é Berhonec Guénett, / péré a zisk er féçon de bedein Doué, / de gontamplein er Bassion, de dostatt / d'er Sacremanteu, ha d'enn devoud ur / Marhue euruss. / KEVRED ÉHUÉ / Litanieu, Noélenneu, Proseu, \&c. / É GUÉNETT, / É ti er Vrederr GALLES, Imprimour / ha Librour, ar Bond enn EntronVaria." (Approbation from 1760)

This collection of canticles will henceforth be referred to as the "Cantikeu".

\section{1 "Meruel zo ret"}

NG noël 17 (1. 1278-1408; 16 stanzas), which I have chosen to name "Meruel zo ret"10 after the first line of the refrain, also occurs in the Cantikeu. ${ }^{11}$ According to Hemon, this noël contains $2.3 \%$ internal rhyme, which places it in Class III and means that it is "probably more recent [than Middle Breton] in origin, but still contain elements taken from older hymns" (Hemon 1956: 1xxi). Given that most of the internal rhymes in the NG noëls are of the "simple vowel rhyme"

8. Note, however, that four lines (325-328) from NG noël 9, a noël on the Three Kings, reappear somewhat altered in a Bas-Vannetais Chantefable de Noël collected by Donatien Laurent from a speaker born in 1907 (LAURENT 1968: 164).

9. The noëls accompanying the Pastoral var Guinivelez Jesus-Christ unfortunately remain mostly unpublished (cf. CHOTZEN 1941, 1942; HAMILTON 1976, 1984). This has made a direct comparison of these with the NG noëls impossible.

10. We may add these attestations of meruel zo ret to the list of examples of VERBAL NOUN + zo + ret discussed by KERRAIN (1998: 109) and LE MENN (1998b: 59$60)$.

11. Entitled "Cantic spirituel / Ar honn Finieu déuéhan", with 21 stanzas, p. 62-64. 
type, there is the very real possibility that the few internal rhymes we do find in the Class III noëls are completely accidental.

\subsubsection{Stanza structure}

Both versions of this noël have a refrain to be sung after each stanza (cf. Croix 1981: 1184-1185, where the refrain is discussed).

\begin{tabular}{|l|l|}
\hline NG refrain (Hemon 1956: 66) & The Cantikeu refrain \\
\hline Meruel zo ret. ${ }^{*}$ & Merhuel zou rett. \\
Songeam, coh ha iouanc, & Chonjamp, ${ }^{* *}$ coh ha iouanc, \\
Prinset ha baronnet. & Princett ha Baronnett, \\
Meruel zo ret. & Merhuel zou rett. \\
\hline
\end{tabular}

* The first line of the refrain is grouped with the preceding stanza in the NG version.

** The first time the refrain is given, chonjamp occurs in its older form sonjamp.

The NG version is arranged into stanzas with six lines of six syllables each, the Cantikeu version into stanzas of three lines of twelve syllables. This difference is purely a matter of page layout, and, even though neither the NG nor the Cantikeu present the text as such, the rhyme pattern -a-abb actually invites the following layout, with a rhyme pattern aabb:

\begin{tabular}{|c|c|}
\hline NG stanza 5 (Hemon 1956: 68) & The Cantikeu stanza 4 \\
\hline Allas, peherion peur, / Sellet cotibunant, & Allass! Péherion queih, chongett \\
ga v quet pliadur / Ou vezouet e-r (bet)-man. & $\begin{array}{c}\text { N'enn dé qué plijadur buhé Dein er } \\
\text { Bett-man; }\end{array}$ \\
Mais e-n tourmant song(et) & D'enn tormanteu chonged \\
En des er ré dannet. ${ }^{*}$ & enn-dess er-ré Dannett \\
\hline
\end{tabular}

* Most stanzas end in -et, providing a linking rhyme with the first line of the refrain, which ends in -et.

The restructuring eliminates the existence of lines without end rhyme. The rhyme pattern, which is probably original, generally survives better in the NG, as can be seen from the following stanza: 


\begin{tabular}{|c|l|}
\hline NG stanza 16 (Hemon 1956: 72) & The Cantikeu stanza 17 \\
\hline Allas, peherion peur, / En ellet a crenou & $\begin{array}{l}\text { Allass! Péherion queih, enn FEled a } \\
\text { greinou }\end{array}$ \\
Ou guellet er santancë, / Pequer cruel vezou. & $\begin{array}{l}\text { E cléhued er Santanss, peh-kenn orible } \\
\text { vou: } \\
\text { Siouah! er péhour peur, pétra vou } \\
\text { à-nehou? }\end{array}$ \\
Ha huy, peherion bras & \\
\hline Ne ret quet cals a cas! & \\
\hline
\end{tabular}

Here we can see how the original, relatively complicated structure $(2 \times 12+2 \times 6)$, which is preserved in the $\mathrm{NG}$, was changed into three lines of twelve syllables, with a simple rhyme scheme aaa, in the Cantikeu.

Due to restrictions to the length of this paper and the limited interest this quite long noël presents (10 stanzas in the NG, 21 stanzas in the Cantikeu), it is not reproduced in the appendix.

\subsection{Melody, jouay - A Middle Breton noël surviving in the Vannetais tradition?}

NG noël 15 (1. 995-1071; 19 stanzas), here entitled Melody, jouay after its opening line, ${ }^{12}$ appears to represent the remains of an actual Middle Breton composition, at least with regard to the versification. The noël reappears in the Cantikeu. ${ }^{13}$ According to Hemon, $36 \%$ of the required internal rhymes are present in the NG version, the highest among the noëls in the NG. This noël presents a very peculiar stanza structure, with one line of eight syllables with a fixed caesura after the fourth in the Cantikeu (presented in the NG as two lines of four syllables with no end-rhyme), followed by the same two hemistichs, but with an alteration or addition to the second hemistich to provide internal rhyme and two additional syllables, giving the line ten syllables. This ten-syllable line is in turn followed by a regu-

12. The first stanza of the NG (with the opening line "Melody, jouay") appears as a refrain in the Cantikeu version.

13. Entitled "Cantic spirituel / Noélenn énn inour d'er Gannédiguiah à Jésuss", with 20 stanzas, p. 81-83. It is reprinted with minor changes in the 1804 re-edition of the Cantikeu. This version is in turn used as the basis of a version in the Choége nehué a gannenneu spirituel [...] é Guénet, 1829, p. 80-82. 
lar twelve-syllable line with a caesura after the sixth syllable, internal rhyme, and end rhyme with the preceding line.

\subsubsection{Independent branches}

While NG has usually preserved the internal rhyme of Melody, jouay better than the Cantikeu, the latter sometimes preserves the internal rhyme where it appears to have been lost in the NG. This may be taken as proof that the two versions derive independently from a common Vannetais source, which in turn derives from the hypothetical "Middle Breton" proto-noël. The following stanza will demonstrate the importance of the Cantikeu:

\begin{tabular}{|l|l|}
\hline NG stanza 17 (Hemon 1956: 57) & Translation (Hemon) \\
\hline $\begin{array}{l}\text { En ennet bihan, / Hac a canné, } \\
\text { En n-ennet bihan e nos-sé a ganné : } \\
\text { "Groit melody de Doué ha ni gray eué." }\end{array}$ & $\begin{array}{l}\text { The little birds, / Sang, } \\
\text { The little birds that night sang: } \\
\text { "Give praise to God and we shall (praise } \\
\text { Him) also." }\end{array}$ \\
\hline The Cantikeu stanza 20 & Translation \\
\hline $\begin{array}{l}\text { Enett bihan... Ol a ganné; } \\
\text { Enett bihan enn noss-man a ganné } \\
\text { Guett mélodi Doué, ha ni ol groamb éhué. }\end{array}$ & $\begin{array}{l}\text { Little birds... They all sang; } \\
\text { Little birds on this night sang } \\
\text { With praise of God, and we all shall do it } \\
\text { also. }\end{array}$ \\
\hline
\end{tabular}

Here we can see how the alteration to the second line, with $\mathrm{Ol}$ being replaced by enn noss-man 'on this night'14 in the Cantikeu, provides the expected internal rhyme with bihan and $a$ ganné. The different deixis in e nos-sé 'on that night' in the NG is unremarkable and actually fits the context better, but it ruins the internal rhyme. We may also note that the first hemistich of the first two lines (actually the first line and the first hemistich of the third line in the layout of the NG) is hypermetric, having five instead of the expected four syllables (unless bihan is read as monosyllabic). On the other hand, the last line of the stanza may be better preserved in the NG. At least, the line shows both internal rhyme between the syllable before the caesura (Doue ) and the in-rhyme (êué), and an additional, embedded

14. enn noss-man 'on this (very) night' must refer to Christmas Eve, i.e. the night when the noël is being sung. 
internal rhyme in the second hemistich (ni gray). The Cantikeu version on the other hand only has the primary internal rhyme between Doué and éhué, which is very meagre for a twelve-syllable line.

\subsubsection{The superiority of the $N G$ version}

Another stanza will demonstrate the general superiority of the NG over the Cantikeu:

\begin{tabular}{|l|l|}
\hline NG stanza 9 (Hemon 1956: 55) & Translation by Hemon \\
\hline Ha houeh pedamp / Ha ma vezou, & And still let us pray / That she may be \\
Ha houeh pedamp eué ha ma uezou & And still let us pray also that she may be \\
Hon guir aduoca[de]s dirac hon guir Autru. & Our true advocate before our true Lord. \\
\hline The Cantikeu stanza 11 & Translation \\
\hline Honeh pédamp... Hag a vezou; & She, let us pray... who will be \\
Honeh pédamp hag hemp fautt a vezou, & She, let us pray, flawless, who will be \\
Pouissand Avocadess dirac hi Mab Autrou. & A powerful advocate before her Son, the Lord. \\
\hline
\end{tabular}

As well as the interesting end rhyme between vezou ${ }^{15}$ and $\operatorname{Autr}[0] u,{ }^{16}$ there are a number of other points to note. We may assume that an original houeh /hosx/ 'still', preserved as such in the NG, was misread as honeh 'she (there)' (due to the trivial confusion of $\langle\mathrm{u}>$ and $\langle\mathrm{n}\rangle$ ) by a copyist at some point between the common Vannetais precursor and the Cantikeu. This miscopying lead to the syntactically awkward Honeh pedamp 'she, let us pray', which is in turn corrected to the more straightforward Pedamp honeh in the 1804 re-edition of the Cantikeu.

Another interesting aspect of this stanza is the likely internal rhyme in the second line between houeh, eué and vezou. In Vannetais of the 17th century, this would no longer be a triple rhyme, as can be readily observed. If transposed into Standard Middle Breton, we

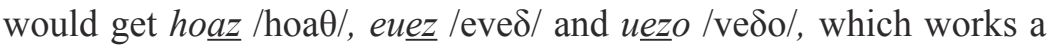
lot better (rhyme between $/ \theta /$ and $/ \delta /$ is fully regular). However, we would need the rare variant hoez, hoaez $/$ hos $\theta /$ to make the rhyme

15. The form vezou, with preserved medial / $\delta /$, is not foreign to Early Vannetais and cannot be used to argue a non-Vannetais origin.

16. If taken at face value, this might point to inland Haut-Vannetais, a central or eastern form of Cornouaillais (both $[-\mathrm{u}]=[-\mathrm{u}]$ ) or Trégorrois $([-\mathrm{o}]=[-\mathrm{o}]$ ). 
perfect. As I have argued elsewhere (Widmer \& Jørgensen 2011: 13), /o\&/ was still retained in Eastern Cornouaille at the time An Buhez Sant Gwenôlé was composed and, indeed, we find hoez, hoaez /hoz $\theta /$ in this text. If taken at face value, this might point to an Eastern Cornouaillais origin of the noël, ${ }^{17}$ though without corroborating evidence, this constitutes little more than speculation. It should also be noted that houeh probably does not constitute an obligatory member of the internal rhyme.

We may make a final observation on the stanza: both versions agree on having Autrou 'Lord' at the end of the last line, which ensures that it was present there in the common Vannetais precursor, though not necessarily in the "Middle Breton" original. If we do assume that Autrou was present in the original and in this position, it ought to participate in the internal rhyme. When Autrou 'lord' occurs elsewhere with aut- in obligatory rhyming position in Middle Breton poetry (i.e. line-final or immediately preceding the caesura in a long line) it is apparently always preceded by hep faut 'without fault' or variations thereof (apart from a few cases where rhyme is irregularly absent). ${ }^{18}$ In light of this, it is very tempting to see hemp fautt in the preceding line of the Cantikeu as belonging to this line, having been misplaced at one point. In light of this, one can attempt a very tentative Middle Breton ${ }^{19}$ reconstruction:

\begin{tabular}{|l|l|}
\hline Middle Breton reconstruction & Translation \\
\hline Ha hoez pedamp / Ha ma uezO & And again we pray / That she will be \\
Ha hoez pedamp euez ha ma uezO & And again we pray also that she will be \\
Aduocades, hep faut, / dirac ... $\underline{\text { AutrOU }}$ & Advocate, flawless, before ... Lord \\
\hline
\end{tabular}

Unfortunately, this leaves the third line quite meagre with regard to internal rhyme. Another downside with this reconstruction is the

17. Cf. $\S 6$ below.

18. hep/heb faut $=\underline{\text { autr }}$ (a) ou (B 52, 65, 250, 287, 376, 384, 609, 781; N 293/416, 348/471, 1411/1534; G 438; J 40, 54; Pm. (Trem.) 133, 167; N1. 8, 78, 193, 250);

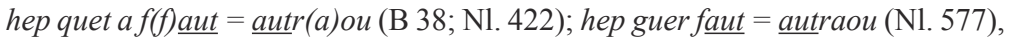
an fault $=$ autrou $(\mathrm{N}$ 668/790).

19. In "proper" Middle Breton we would expect pedomp and maz uezo, but there is no basis for inserting these in the text. 
fact that Aduocades has to have been moved independently to the same place in both branches. An alternative would be to place hep faut first in the last line, having been moved in the Cantikeu and replaced in the NG, thus Hep faut, Aduocades / dirac hon guir Autrou. This would however mean that the obligatory rhyme immediately preceding the caesura was missing.

\subsubsection{Conclusion on Melody, jouay}

It seems very likely that this noël, when originally composed, complied with the Middle Breton system of versification, with full internal rhymes. As argued in $\S$ 4.2.1, the Cantikeu sometimes presents a better reading, which means that this version cannot have been derived directly from that of the NG. On the other hand, the NG and the Cantikeu versions frequently agree on lines which show no preserved internal rhyme, which means that the common precursor of the two cannot have been the "Middle Breton" proto-text, but an intermediary, already somewhat altered text.

The noël Melody, jouay deserves a much more detailed study and edition than is possible here. I will therefore not reproduce it in the appendix, but hope to be able to return to it at a later point.

\section{Noëls imported from the French tradition}

While the linguistic side of the NG has been studied in detail by Hemon (1956) and Jackson (1967), nobody appears to have looked into the sources of the NG. The sole exception is Émile Ernault (1905b), who considered a French origin of noël 6, the only noël he edited, likely. However, Ernault was unable to identify the exact source. Going through various collections of older French noëls, I have identified the French sources for two ${ }^{20}$ other noëls in the NG, namely the older French Nouel pour l'amour de Marie and Or, nous dites Marie (alternatively entitled Chantons je vous en prie). Both of the French pieces are "parody noëls", i.e. noëls originally based on (mainly) secular songs, with the words replaced, but the melody being familiar to the general public.

20. It is likely that other noëls in the NG derive from French originals, only these have not been identified yet. 


\subsection{Nouel poulamour de Marië}

NG noël 8 (Hemon 1956: 11-15), named here Nouel poulamour de Marië after its opening line, clearly derives from an older French noël, Nouel pour l'amour de Marie. ${ }^{21}$ The rhyme pattern, mostly $a \mathrm{~b} a \mathrm{~b}^{22}$ in the French original, has been transformed into what tends to be aabb in Breton (though frequently deficient in both versions). I reproduce here the first stanza of the French and the Breton noëls, with the Breton words showing a direct correspondence in the French version underlined:

\begin{tabular}{|l|l|l|l|}
\hline \multicolumn{2}{|l|}{ Stanza 1 (Poulaille 1942: 284) } & \multicolumn{2}{l|}{ Stanza 1 (Hemon 1956: 11) } \\
\hline 1.1 & Nouel pour l'amour de Marie & 1.1 & Nouel poulamour de Marië \\
1.2 & Nous chanterons joyeusement & 1.2 & Nouel canamp joyeusement \\
1.3 & Quant el' porta le fruyt de vie & 1.3 & Er freh a buhe pe dougas \\
1.4 & Ce fut pour nostre saulvement. & 1.4 & He guir map Jesus on prenas \\
\hline
\end{tabular}

As can be seen, the first three lines are word-for-word translations of the French original, only with the word order changed in the third line. Another stanza is reproduced to give an impression of the close relationship:

\begin{tabular}{|l|l|c|l|}
\hline \multicolumn{2}{|l|}{ Stanza 10 (Poulaille 1942: 285) } & \multicolumn{2}{|l|}{ Stanza 12 (Hemon 1956: 13) } \\
\hline 10.1 & A my nuit cette nuitée & 12.1 & De crais en nos hem geu erbet, \\
10.2 & La doulce Vierge eut enfant & 12.2 & Certain voy er ganedigues. \\
10.3 & Sa robe n'estoit pas fourrée & 12.3 & He dillat ne d-ouen quet doublet \\
10.4 & Pour l'envelopper chauldement & 12.4 & Euit dastum Salver er bet \\
\hline
\end{tabular}

This stanza demonstrates how, even when the translation is not literal, the basic meaning is often preserved. Thus, the French $L a$ doulce Vierge eut enfant is substituted with Certain voy er ganedigues 'Certainly was the birth'.

21. Quoted from Poulaille (1942: 284-286), based on Les Nouelz faitz en lonneur de Jhésuchrist, MARESCHAL et CHAUSSARD, 1506 (earliest dated version).

22. The italics indicate a feminine ending. The French original alternates between lines with feminine and masculine endings, with the odd numbered lines ending in the reduced vowel (hence Marie $\underline{\underline{e}}=$ vië and so on). Since Breton does not have word-final reduced vowels (at least not in this period and dialect), this was ignored in the Breton version. 


\subsubsection{Improving our understanding of the text}

The identification of the French source of Nouel poulamour de Marie allows us to review Hemon's translation and, in a few places, improve upon it. In the second stanza of the Breton noël we encounter what at first sight appears to be a somewhat awkward line.

\begin{tabular}{|c|c|c|c|c|}
\hline \multicolumn{2}{|c|}{ Stanza 2 (Poulaille 1942: 284) } & \multicolumn{3}{|c|}{ Stanza 2 (Hemon 1956: 11) } \\
\hline 2.1 & $\begin{array}{l}\text { Joseph et Marie s'en } \\
\text { allèrent }\end{array}$ & 2.1 & $\begin{array}{l}\text { En din mat Joseph ha } \\
\text { Marie, }\end{array}$ & $\begin{array}{l}\text { The good man Joseph, } \\
\text { and Mary, }\end{array}$ \\
\hline 2.2 & $\begin{array}{l}\text { Ung soir bien tard en } \\
\text { Bethléem }\end{array}$ & 2.2 & Mont de Velem a rezant-y. & They went to Bethlehem. \\
\hline 2.3 & $\begin{array}{l}\text { Ceulx qui tenoyent } \\
\text { hostellerie }\end{array}$ & 2.3 & Nep a delhé ostaleri & Those who kept inns \\
\hline 2.4 & Sy ne les prisèrent riens & 2.4 & $\begin{array}{l}\text { Certein de netra n-ou } \\
\text { presezant y. }\end{array}$ & $\begin{array}{l}\text { Certainly did not press } \\
\text { them to any thing. }\end{array}$ \\
\hline
\end{tabular}

The last line of the NG version, Certein de netra n-ou presezant $y$ is translated by Hemon as 'Certainly did not press them to any thing'. While this translation seems uncontroversial, it does not fit the context particularly well. The corresponding French line reads Sy ne les prisèrent riens 'Certainly did not value them as anything', which instead suggests that we analyze the 3. pl. pret. presezant not as a form of the Vannetais verb presein 'to press' (from OMFr. presser), but rather as a form of the specifically Vannetais verb prezein 'to hold worthy, to value, to deign' ${ }^{23}$ We can note, in connection with the form presezant, that the use of $<\mathrm{S}_{\mathrm{S}}>$ and $<\mathrm{Z}_{\mathrm{Z}}$ in the NG is inconsistent and both may be used for /z/ (from MBret. $<\mathrm{s}>$; cf. Hemon 1956: xxvi-xxvii). A downside with this interpretation is the presence of the preposition de, which seems out of place with the verb prezein. It may have been added by a copyist making the same interpretation as Hemon. This would explain why the line has nine instead of the expected eight syllables.

23. As in NG 35, 1162 preset (past participle) and L'Arm. 88b: Daigner Prefein. The Vannetais word was borrowed from OMFr. preiser, preisier, presier, whereas MidBret. prisaff was borrowed from OMFr. prisier, priser. 


\subsubsection{Identifying the source}

Once we have established that Nouel poulamour de Marie was based on a French original, we may compare it to the various printed French editions of Nouel pour l'amour de Marie and attempt to identify the precise source. An exact identification of the source would provide us with a likely terminus post quem for the translation/adaptation of the noël into Breton. Unfortunately, any identification is complicated by the fact that the printed French editions usually differ very little, apart from minor points of spelling. However, in one instance, we find a significant discrepancy which is reflected in the Breton translation.

\begin{tabular}{|c|c|c|c|}
\hline \multicolumn{2}{|c|}{ Stanza 2 (Poulaille 1942: 284) } & \multicolumn{2}{|c|}{ Stanza 2 (Hemon 1956: 11) } \\
\hline 2.1 & Joseph et Marie s'en allerent & 2.1 & En din mat Joseph ha Marie, \\
\hline 2.2 & Ung soir bien tard en Bethléem, & 2.2 & Mont de Velem a rezant-y. \\
\hline 2.3 & Ceulx qui tennoyent hostellerie & 2.3 & Nep a delhé ostaleri \\
\hline $2.4 a$ & Sy ne les prisèrent riens (as in Poulaille 1942) & & Cert \\
\hline $2.4 b$ & $\begin{array}{l}\text { Ne les priserent pas gramment (as in Block, de } \\
\text { Smidt, etc.) }\end{array}$ & 2.4 & presezant y. \\
\hline
\end{tabular}

As can be seen, the French versions differ in the last line of the stanza. Most versions ${ }^{24}$ have Ne les priserent pas gramment "Did not value them greatly", whereas the version reproduced by Poulaille has Sy ne les prisèrent riens "Surely did not value them as anything". Though the difference is not great, the latter version corresponds exactly to the text of the Breton version, Certein de netra n-ou presezant $y$ 'Surely did not value them as anything', which is why this edition (or a similar one drawing from the same tradition) must be the basis of the Breton translation. The version given by Poulaille also happens to be from the earliest dated edition, Les Nouelz faitz en lonneur de Jhésucrist, dating from 1506. This does not entail, however, that the Breton translation is anywhere near as old as the printed French edition. Only a thorough investigation into the many

24. E.g. the versions reproduced by de SMIDT (1932: 152-153), BLOCK (1983 II: 114-117; reproducing the text of SERGENT, 1537) and MATHER \& GAVIN (1996: 77; reproducing the text of Nicholas Oudet's La Grande bible des noels tant viels que nouveaux, 1684). 
editions of Nouel pour l'amour de Marie, including an answer to the question of whether or not the Poulaille variant is unique, would provide a more solid foundation, but this is outside the scope of this paper. Finally, we also need to keep in mind the possibility that the Breton translation/adaptation may have been based on an oral version of the French noël.

\subsubsection{Accidental internal rhymes}

According to Hemon (1956: 1xx), Nouel poulamour de Marië has $9.2 \%$ internal rhyme, meaning probably seven lines with internal rhyme out of the 76 in the noël. It is accordingly assigned to Hemon's middle category, class II. According to him "at least fragments of the hymns belonging to Class II must be new versions of older hymns" (Hemon 1956: 1xxi). However, when we confront the Breton text with the French original, it becomes clear that many of the internal rhymes may be accidental. To take an example, line 2.3: Nep a delhé ostaleri, looks like it contains an intended internal rhyme, but the corresponding line in the French original, 2.3: Ceulx qui tenoyent hostellerie, shows that it could just be accidental, being the result of a word-for-word translation. It may be worth noting that in the few cases where the internal rhyme is more complicated, involving either a vowel other than /e/ or a vowel followed by a consonant, the rhyme occurs in a stanza which has no correspondence in the French original. This applies to 15.1: Ny ou suply, bras ha bihan; 15.3: Ma h-ehemp d-er joy dialhué; ${ }^{25}$ 17.1: Ha, Itron Varië, ny [ou] pet; 19.2: Ne vihemp quet euit bretat. The only exception is 16.1: Pe ellemp ur gueh monet dehy, which corresponds to the French line 15.1: Sy une fois y pouvons estre. This could be taken as an indication that these stanzas, which have no correspondence in the French original, have been taken from a different source, with a higher proportion of internal rhyme.

\subsection{Leueret dimp Marie}

The last noël of the NG, number 22, also derives from a

25. This is possible as a Standard Middle Breton internal rhyme, cf. J 182: Monet [...] dan ioa dialahez. 
French original, the old ${ }^{26}$ and very popular Or, nous dites Marie ${ }^{27}$ (alternatively named Chantons je vous en prie). The French noël is characterized by a series of questions introduced by $\mathrm{Or}$, nous dites Marie. This is translated into Breton ${ }^{28}$ as Leueret dimp Marie and consequently, I have chosen this as the Breton title. Unfortunately, the NG manuscript breaks off after only seven stanzas of what would presumably have been a quite long noël, at least if it matched the French original with its 21 stanzas. ${ }^{29}$ The Breton noël is assigned by Hemon to Class I ("new versions of older [Middle Breton] hymns") on the basis of a remarkable $25 \%$ internal rhyme, the third-highest in the entire NG. Of the 28 lines in the manuscript (seven quatrains of twelve syllables), only 18 lines are preserved well enough to allow us to judge whether or not they have an internal rhyme. This probably means that Hemon counted $4 \frac{1}{2}$ internal rhymes. Unfortunately, the exact method by which Hemon arrived at the percentages is not spelled out, but it is likely that the line he counts as half has an apparent internal rhyme, but with the in-rhyme placed on the antepenultimate syllable instead of the penultimate. The most likely candidate in noël 22 for a line with antepenultimate in-rhyme is line 2000/7.1: Leueret dimp, Marië, ma h-oue(h)-hui d-en er 'Tell us, Mary, where were you at the hour'. However, since the penultimate syllable consists of the proclitic $d$-en, the internal rhyme may be considered completely regular. This is because antepenultimate in-rhyme is allowed when the penultimate syllable consists of a proclitic (cf. Jørgensen 2007: 59-94).

26. Probably dating from the 15 th century, cf. de SMIDT $(1932: 37,120)$.

27. Reproduced by LEMEIGNEN (1876: 7-13), de SMidT (1932: 117-120), Poulaille (1942: 301-304), BLOCK (1983 II: 66-70), MATHER \& GAVIN (1996: 81).

28. This French noël was also used as the basis of a different Vannetais adaptation, occurring in the Cantikeu (p. 75-77). The following stanza demonstrates the occasionally close relationship between the two: Larett temp-ni, Mari / Menn hou cavass en AEl / Pé zégassas teoh-hui / Ur hevel ker-santel? / Em hambric me hunon / E leh dein n'em guélé, / E hoainn énn Oréson / Er vro à Galilé (p. 77) corresponding to the French - Or, nous dites, Marie / Où étiez-vous alors / Quand Gabriel Archange / Vous fist un tel rapport? / - J'étois en Galilée / Plaisante région / En ma chambre enfermée / En contemplation.

29. Hemon was able to make out the existence of eight more stanzas of noël 22, but unfortunately decided not to reproduce the "few words left" (HEMON 1956: ix). With the help of the French noël, even one or two words could allow us to identify the stanza. 


\subsubsection{The basic structure}

It should be noted that the Breton version in the NG is divided into four lines of twelve syllables instead of eight lines of six syllables as the French. This is purely a matter of page layout, and when comparing the two versions, I have divided the Breton twelvesyllable lines into two six-syllable lines, to match the French. This must anyway be the original structure of the Breton noël, since the frequent end rhyme between the odd-numbered lines would otherwise be inexplicable, occurring in the middle of the twelve-syllable line. The fact that end rhyme is often missing in odd-numbered lines is not a strong argument in favour of the twelve-syllable line, since the same defect is encountered in the French noël. ${ }^{30}$

A stanza is reproduced to demonstrate the affinity between the French and Breton noëls:

\begin{tabular}{|l|l|l|l|l|}
\hline \multicolumn{2}{|l|}{ Stanza 4 (Poulaille 1942: 302) } & \multicolumn{2}{l|}{ Stanza 7 (Hemon 1956: 105) } & Translation (Hemon) \\
\hline 4.1 & - Or, nous dites, Marie & 7.1 & Leueret dimp, Marië, & Tell us, Mary, \\
4.2 & Où étiez-vous alors & 7.2 & $\underline{\text { ma h-oue(h)-hui d-en er }}$ & where were you at the hour \\
4.3 & Quand Gabriel Archange & 7.3 & Ma vezau[h] saludet & When you were saluted \\
4.4 & Vous fist un tel rapport? & 7.4 & guet en el Gabriel? & by the angel Gabriel? \\
4.5 & - J'étois en Galilée & 7.5 & "En Galile e h-ouen & "I was in Galilee \\
4.6 & Plaisante région & 7.6 & $\underline{\text { en contemplation, }}$ & in contemplation, \\
4.7 & En ma chambre enfermée & 7.7 & $\underline{\text { E cambrë hac e study }}$ & In the room, studying \\
4.8 & En contemplation. & 7.8 & hemp mui dilation." & without more delay." \\
\hline
\end{tabular}

* The rendering of Fr. alors with Vann. $d$-en er 'at the hour' might be significant, as it could indicate familiarity with Gallo. In Gallo (and in Western French in general) stressed VLat. /ọ/ in an open syllable became /u/, hence Lat. hōra 'hour' yielded [ur] instead of Standard French [ør]. Therefore the etymological connection in Gallo between aloure 'alors' (specifically given for Morbihan by Auffray 2007: 81,390) and oure 'heure' is still present and this connection may have prompted the literal translation of alors to Breton $d$-en er 'at the hour'.

** With French en contemplation being translated both by Breton en contemplation and $e$ study, cf. GIB ${ }^{1}$ 2989: studiañ 1. étudier; 2. réfléchir (à); 3. avoir en vue.

30. Cf. MATHER \& GAVIN (1996: 6): "Almost all masculine pairs [in even-numbered lines] of this noel rhyme or use assonance, while the feminine pairs [in oddnumbered lines] variably employ rhyme, assonance, or no coordinating device at all." 


\subsubsection{Reconstructing from the original}

We can use the French original to reconstruct parts of the Breton noël which have been lost due to damage to the manuscript:

\begin{tabular}{|c|c|c|c|c|}
\hline \multicolumn{2}{|c|}{ Stanza 3 (Poulaille 1942: 302) } & \multicolumn{2}{|c|}{ Stanza 3 (Hemon 1956: 104) } & Tentative reconstruction \\
\hline 3.1 & - Or, nous dites, Marie & 3.1 & Leueret dimp ... & Leueret dimp [Marie] \\
\hline 3.2 & Que vous dit Gabriel & 3.2 & $\ldots \underline{\text { as }}$. & [pe lar]as [Gabri]el ${ }^{*}$ \\
\hline 3.3 & Quand vous porta nouvelle & 3.3 & Pe consas & Pe consas [a douere] $]^{\star *}$ \\
\hline 3.4 & Du vrai Dieu éternel? & 3.4 & ......... eternel & [ar guir Doue] eternel \\
\hline 3.5 & - Dieu soit ô toi, Marie & 3.5 & Mari . & Marie [?] \\
\hline 3.6 & Dit-il sans fiction & 3.6 & ......... enuh & [Doue a uezo?] enuh \\
\hline 3.7 & Tu es de grâce emplie & 3.7 & En ... en . & [?] \\
\hline 3.8 & Et bénédiction. & 3.8 & ................. et. & [?] \\
\hline
\end{tabular}

* Or possibly pe laras duh en el 'what did the angel say to you', cf. stanza 6: pe laras duh en ail, translating the French Que vous dit Gabriel.

** Cf. stanza 2, where Qui porta la nouvelle is translated by A consas duh quentanf / a douere.

Naturally, the reconstruction is uncertain, but even the few remains of the stanza allow us to identify to which French stanza it corresponds.

\subsubsection{French parody noëls and the copying of structure and content}

A characteristic of the French parody noëls (such as the two discussed here) is the fact that not only the syllable count and the rhyme patterns ( $a \mathrm{~b} a \mathrm{~b}, a \mathrm{~b} a \mathrm{~b} c \mathrm{~d} c \mathrm{~d}$, etc.), but frequently also the actual rhymes (e.g. $-i e=-i e$ ), and sometimes even the actual words could be transferred to the noël from the original popular song which provided the melody. In the case of the Breton translation, ${ }^{31}$ something similar seems to have happened. Not only were the lines translated, but in this particular case, the predilection for end-rhyme in -ie in the oddnumbered lines of the original French noël (instigated no doubt by the recurring stanza-initial $\mathrm{Or}$, nous dites Marie) was frequently carried over into the Breton version. Another characteristic of this particular French noël is the use of learned, Latin nouns in -tïon, -cïon, -ïon in the sixth and the eighth line of most stanzas. This means that we

31. Or adaptation, given the limitations imposed by the poetic form. 
often have odd lines ending in -ie and even lines ending in -ïon. If structured into twelve-syllable lines, as the Breton noël in the NG, instead of six-syllable lines, as the French original, it will create the appearance of internal rhyme. In fact, when structured this way, the third stanza of the French noël, reproduced above, is very close to being perfect according to Hemon's understanding of Middle Breton versification (if we ignore the word-final schwa):

\begin{tabular}{|l|l|}
\hline \multicolumn{2}{|l|}{ Stanza 3 (Poulaille 1942: 302) } \\
\hline 3.1/3.2 & - Or, nous dites, Marie / Que vous dit GabrịEL \\
3.3/3.4 & Quand vous porta nouvelle / Du vrai Dieu éternEL? \\
3.5/3.6 & - Dieu soit ô toi, Marie / Dit-il sans fictioN \\
3.7/3.8 & Tu es de grâce emplie / Et bénédictioN. \\
\hline
\end{tabular}

This is not to say that the French noël actually has intentional internal rhyme, only that the rhyme structure already present in the French original is bound to increase the percentage of internal rhyme in the Breton version and possibly give a misleading impression.

\subsubsection{A re-evaluation of the percentage of internal rhyme}

Once we discount the internal rhymes either provoked by wordfor-word translations or predetermined by the structure of the French noël, we are left with only one unquestionable case of internal rhyme (and even that is an open syllable rhyme in - $i$-, as predicted by the French original), namely stanza 4: Pe laras-enf dih-uy / mait e h-oueuh beniguet? This leaves us with $5.55 \%$ internal rhyme, a very different number from the $25 \%$ posited by Hemon. We may combine this with the fact that, pace Hemon, a twelve-syllable line with internal rhyme only between the sixth and the eleventh syllable is not strictly speaking correct according to the Middle Breton rules of versification. Usually, a twelve-syllable line requires some form of additional rhyme, either an embedded secondary rhyme or a third word-final syllable participating in the main internal rhyme (cf. Ernault 1912: 35). In light of this, I see no particular reason to assume that this noël was originally composed according to the Middle Breton rules of versification as assumed by Hemon. Rather, it seems to be a fairly literal translation from French (as literal as the poetic form allows). 


\section{Conclusion}

So, what can we say on the basis of the preceding notes? First of all, it is clear that the diverse nature of the noëls has consequences for the dating of the NG. It is perfectly possible, even probable, that the NG is a collection of noëls from different periods. Just because a few of the noëls can be plausibly argued to date back to the Middle Breton period, we cannot infer, as Hemon does, that "the hymns contained in our manuscript were composed during the first half of the seventeenth century." (Hemon 1956: xi). Only the few noëls which show a relatively high percentage of internal rhyme (such as noël $6,9,15$ and 21) can be dated this early in their original form. The majority could easily be closer in origin to the proposed 1680 date of the manuscript.

The same argument may be used in connection with the question of authorship. The noëls in the NG simply seem too diverse to have been written by a single author (an idea entertained by Hemon 1956: xi). To be sure, many of the noëls, both the ones translated from French and the ones with a very low percentage of internal rhyme, may be the work of a single author/translator, but the same person can hardly have been responsible for a complicated composition such as noël 15, Melody, jouay.

Regarding the dialect of the noëls in NG, Hemon (1956: xi) took them to have been originally composed in Vannetais Breton. The occurrence of distinctly non-Vannetais forms in the NG was explained by Hemon as being due to "the author or authors having seen hymns written in Middle Breton or in some other dialect of Early Modern Breton" (Hemon 1956: xi). This may well be correct in the case of the noëls with a low percentage of internal rhyme, ${ }^{32}$ but what about the noëls with a high percentage of internal rhyme? Were they also composed in Vannetais Breton? In his discussion of the original dialect of the NG, Hemon (1956: lxxi-lxxii) only treats the end rhymes. He concludes that these are, with very few exceptions, either uninformative or specifically Vannetais in nature. However, end rhymes are no certain guide to the original dialect. This is because the modern system of versification, consisting solely

32. As argued in $\S 2.6$, the miscopying of gries as grieff could indicate that even some of these were transferred from non-Vannetais Breton. 
of syllable count, caesura and end rhyme, will have been familiar to many copyists. Therefore the noëls in NG could easily have been adapted to Vannetais Breton in the course of copying. Hence, the presence of a Vannetais end rhyme does not reveal much more than the general linguistic form of the NG, namely that Vannetais scribes worked on prestages of the NG.

What is more interesting for the prehistory of the NG is the dialectological nature of the surviving internal rhymes. NG does show a few instances of what may be preserved /oc/ in internal rhyme, a potential Vannetais feature, in noël $21^{33}$ and possibly in noël $15 .^{34}$ There is evidence, however, for a relatively late survival of /o\&/ in Eastern Cornouaillais (cf. § 4.2.2, Jørgensen 2009: 114-115 and Widmer \& Jørgensen 2011: 13) as well as sporadic preservation elsewhere in Middle Breton, which means that these instances cannot be taken as being Vannetais beyond doubt. On the other hand, the rhyme Langroes = casty twice in NG $21^{35}$ works much better with/oa/, which would point to some form of KLT Breton. What would clinch the argument would be a solid example of a rhyme between the reflexes of word-final $*_{-} V \theta$ and $* V x$, since these would only merge in Vannetais. Unfortunately, we appear to have no such examples. We may, on the other hand, have an example of $-V \theta$ rhyming with $V \delta$ in noël $15,{ }^{36}$ which would most likely not function in Vannetais Breton, unless the noël was very old (cf. Jackson 1967: 681-684 for the development of non-initial $* \theta$ in Vannetais). While the material is clearly too meagre to allow us to pass judgement on the matter, it does raise a question which appears not to have been addressed previously: was Vannetais of the late 16th and early 17th century, which will already have been linguistically quite distinct from Standard Middle Breton, ever used for compositions with internal rhyme?

33. 1. 1910: E huésas p(ar)fait er gouet doucë 'He sweated his sweet blood truly'.

34. 1. 1029: Ha houeh pedamp eué ha ma uezou 'And still let us pray also that she may be', cf. $\S 4.2 .2$.

35. 1. 1945: E Langroes e gousant casty and 1. 1961: E Langroes cou consant casty, both probably 'On the cross suffering punishment'.

36. 1. 1029: Ha houe[z] pedamp eué[z] ha ma uezou 'And still let us pray also that she may be', cf. $\S$ 4.2.2. Unfortunately, houe[z] is not an obligatory part of the rhyme. 
Above all, the preceding notes highlight an important point: that we should be wary of automatically regarding poetry of poor quality in the Early Modern Breton period, such as the Early Vannetais noëls, as having come about through a process of deformation by successive copying, of an earlier immaculate stage with correct rhyme and syllable count (thus apparently implied in Hemon 1956: lxxi). While this is most likely correct for some of the noëls in the NG, such as Melody, jouay, whose complicated stanza and rhyme structure probably ensures a once well-formed composition, I believe the preceding notes bear out that that is not necessarily always the case. Nouel poulamour de Marie and Leueret dimp Marie are most likely unembellished translations/adaptations, without much regard to the rules of versification (or to put it differently, with about as little regard to the rules of versification as the French originals show). There is no need to assume an immaculate pre-stage for these noëls.

\section{Bibliography}

Auffray Régis, Le Petit Matao, Rennes, Rue des Scribes Éditions, 2007.

BLock Adrienne F., The Early French Parody Noël, I-II, Studies in Musicology, No. 36, Ann Arbor, Michigan, UMI Research Press, 1983.

Chotzen Th. M., «Une survivance des mystères en Bretagne», Neophilologus 26/1, 1941, p. 161-185.

Chotzen Th. M., «Une survivance des mystères en Bretagne (Additions et rectifications)», Neophilologus 27/1, 1942, p. 91-94.

CroIX Alain, La Bretagne aux $16^{e}$ et 17 e siècles. La vie - La mort - La foi, I-II, Paris, Maloine S.A. Éditeur, 1981.

ERNAUlt Émile, «Nouvelles études vannetaises. I. Le Prône de 1631 », Revue Morbihannaise 9, 1905a, p. 80-92, 264-268.

ERNAUlt Émile, «Nouvelles études vannetaises. II. Le Cantique des Signes de Jugement», Revue Morbihannaise 9, 1905b, p. 283-294.

ERNAULT Émile, L'ancien vers breton, Paris, Honoré Champion, 1912.

GMB = ERNAULT Émile, Glossaire moyen-breton, I-II, Paris, E. Bouillon, 1895-1896.

HAMILTON Noel, «Hiniveles Ar Mabic Jesus», Zeitschrift für celtische Philologie 35, 1976, p. 102-157. 
HAMILTON Noel, «Hiniveles Ar Mabic Jesus», Zeitschrift für celtische Philologie 40, 1984, p. 228-274.

Hemon Roparz, Christmas Hymns - In the Vannes dialect of Breton, Dublin, Dublin Institute for Advanced Studies, 1956.

JACKSON Kenneth Hurlstone, A Historical Phonology of Breton, Dublin, The Dublin Institute for Advanced Studies, 1967.

JøRGENSEN Anders Richardt, Contributions to the History of the Breton Language - Studies in Etymology, Versification and Historical Phonology, PhD thesis, University of Copenhagen, 2007.

JøRGENSEN Anders Richardt, "The Vowel Phonemes of The Life of Saint Gwennole with a Note on the Etymology of Breton diner 'penny'», in Stefan Zimmer (ed.), Kelten am Rhein. Akten des dreizehnten Internationalen Keltologiekongresses. Zweiter Teil, Philologie - Sprachen und Literaturen, Mainz am Rhein, Philipp von Zabern, 2009, p. 111-120.

KERRAIN Mark, «Notennoù yezh. 19. Br. mont zo ret, mervel zo ret, h.a.», Hor Yezh 214, 1998, p. 109.

LAURENT Donatien, «Une chantefable de Noël en pays Pourlet : la "trajelie"», Arts et traditions populaires 16, 1968, p. 153-172.

Le Menn Gwennole, "Cantiquou Spirituel" (1642). Premier recueil de Cantiques bretons, Saint-Brieuc, Skol, 1997.

Le Menn Gwennole, Tragedien Sacr par Jan Cadec. Premier texte trégorois (1651 ?), Saint-Brieuc, Skol, 1998a.

LE MENN Gwennole, «Notennoù yezh. 20. Br. mont zo ret, mervel zo ret, h.a.», Hor Yezh 215, 1998b, p. 59-60.

LEMEIGNEN Henri, Vieux Noels composés en l'honneur de la naissance de Notre-Seigneur Jésus-Christ - Noels très-anciens - Noels des XVII ${ }^{e} \&$ XVIII ${ }^{e}$ siècles, Nantes, Libaros, 1876.

LOTH Joseph, «Le plus ancien texte suivi en breton de Vannes», Annales de Bretagne 20, 1905, p. 341-350.

Mather Betty Bang \& Gail GAVIn, The French Noel. With an Anthology of 1725 Arranged for Flute Duet, Bloomington and Indianapolis, Indiana University Press, 1996.

Poula ILle Henry, La Grande et Belle Bible des Noëls Anciens du XII au XVI siècle, vol. 1, Paris, Albin Michel, 1942.

SMIDT J.R.H. (de), Les noëls et la tradition populaire, Amsterdam, H.J. Paris, 1932.

WidMER Paul \& Anders Richardt JøRGENSEN, An Buhez Sant Gwenôlé - Das Leben des heiligen Gwenole, Vienna, Praesens Verlag, 2011. 


\section{Appendix}

The French noëls from Poulaille (1942) are given on the left side and the corresponding Breton noëls from the NG are given on the right side. The stanza order of the French noëls has been kept.

\section{Nouel pour l'amour de Marie} Poulaille 1942: 284-286

1. Nouel pour l'amour de Marie Nous chanterons joyeusement Quant el' porta le fruyt de vie Ce fut pour nostre sauvement.

2. Joseph et Marie s'en allèrent Ung soir bien tard en Bethléem Ceulx qui tenoyent hostellerie Sy ne les prisèrent riens

3. S'en allèrent parmy la ville De huys en huys logis quérant A l'eure la Vierge Marie Estoit bien près d'avoir enfant

4. S'en allèrent chez un riche homme Logis demander humblement Et on leur respondit en somme Avès des chevaulx largement?

5. Nous n'avous qu'ung bœuf et ung âne Voyès les si près l'huys devant Vous ne semblès que truendailles Vous ne logerès point céans

6. Ils s'en allèrent chez un autre Logis demander pour argent Et on leur répondit en outre Vous ne logerès point céans...

7. Joseph si regarda ung homme Qui l'appele « meschant paysant » Où mène ceste jeune femme Qui n'a point plus hault de quinze ans

[6.1 Ils s'en allèrent chez un autre]

[4.2 Logis demander humblement]

[4.3 Et on leur respondit en somme]

8. Joseph si regarda Marie Qui a le cœur triste et dolent

\section{Nouel poulamour de Marie} Hemon 1956: 11-15

1. Nouel poulamour de Marië, Nouel canamp joyeusement. Er freh a buhe pe dougas, He guir map Jesus on prenas.

2. En din mat Joseph ha Marie, Mont de Velem a rezant-y. Nep a delhé ostaleri Certein de netra n-ou presezant y.

3. Dre er guer a Belem e hezant. Caffuouet logeris ne resant. Er guirhies Vari hem ober gouab, A yo prest de ganein he map.

4. Joseph goulen gant un hostis Euit ergant e logeris. Deguet Joseph e voy goulenet: "Ha huy ou hues cals a ronset?"

5. "Nen des guenemp meit un aigeon, Hac un asen in prouision." "Ne doh namait louidion. Certein ne lochet quet aman."

6. De ty un aral e h-esant Goulen logeris euit argant; Hac e voy lauaret dehé, En ty zo ray a tud a oé.

7. Joseph a rancontras unan, Hac er galuas meschant truant, Ma-n e costé er verh iouanc-se, Namait penzec vle ne doué.

8. De ty un aral e h-esant Goulen logeris humblement. Ostis en ty a respondas: "En ty man ne logë namaint tud bras."

9. Joseph a yo perderieus, A sellas Marie truheus: 
En lui disant « Ma chiere amie Ne logerons-nous aultrement?

9. J'ay là veu une vieille estable Logeons nous-y pour le présent Al'eure la Vierge Marie Estoit bien près d'avoir enfant.

10. A my nuit cette nuitée La doulce Vierge eut enfant Sa robe n'estoit pas fourrée Pour l'envelopper chauldement.

11. Elle le myst emmy la crèche Sur ung peu de foin seulement Une pierre dessoulz la tête Pour reposer le Tout Puissant.

12. Très chières gens ne vous déplaise Se vous vivès bien povrement Se fortune vous est contraire Prenèz le patiemment.

13. En souvenance de la Vierge Qui print son logiz povrement En une estable descouverte Qui n'estoit point fermée devant.

14. Or, prions la Vierge Marie Que son filz vueille supplier Qu'il nous doint mener telle vie Qu'en Paradis puissions entrer.

15. Sy une fois y pouvons estre II ne nous fauldroit plus rien Ainsi fut logé nostre maistre Le doulx Jhésus en Bethléem.
"Ac er-mes e lochem-ni bité? Conzet doheint me caranté." -

10. "Ur coh marchaussi zo venont. Logeamp enou ha damp presant." Ha huy mamm Doué ha rouanes, A voy loget en peuranté.

12. De crais en nos, hem geu erbet, Certain voy er ganedigues. He dillat ne d-ouen quet doublet Euit dastum Salver er bet.

11. En ur coh ty repozesant. Ar un nebet fouen a cauezant E voy gannet hon Roy puissant. Nep na gredouh a zo meschant.

13. Entro'oh, tud vat ha truheus, Euit huy bout en peurante. Mar ou hues fortunic e-r bet In pacientait cameret.

\section{[10.4 A voy loget en peuranté. $]$}

14. Pedamp er Guirhies a truhe Ma ray dim he map trugare, Herué er vuhé a cassehemp, D-er barradoues ol ma h-ehemp.

15. Ny ou suply, bras ha bihan, En Tat, er map, er Spered Gloan, Ma h-ehemp d-er joy dialhué, Deuat Jesus hac en ailleé.

16. Pe ellemp ur gueh monet dehy, Tra e-r bet mat ne goulemp muy. Loget [v]oy hon maistr e-r stat-man $\mathrm{Pe}$ des quentan ar bet-man.

17. Ha, Itron Varië, ny [ou] pet, Pedet hou guir vap beneguet, Euit ma vihem coloquet E-r barradoues de fin er bet.

18. Marië, refugë er peherion, Ny ou pet sur a guir calon, Ellë ma un es enouh confiancë, Hon lacait ol en assurancë. 
19. Car assuret, hemp secour Ne vihemp quet euit bretat Dirac ur jugë, a guelou scler Penaus e vo ol hun affairë.

Or, nous dites Marie

Leueret dimp Marie

Poulaille 1942: 301-304

Hemon 1956: 103-105

Ref. Chantons je vous en prie

Par exultation

En l'honneur de Marie

Pleine du grand renom.

1. Pour tout l'humain lignage

Remis hors du péril

Fut transmis un message

A la Vierge de prix

Nommée, fust Marie

Par destination

De royale lignée

Par génération.

2. - Or, nous dites, Marie

Quel fust le messager

Qui porta la nouvelle

Pour le monde sauver?

- Ce fust Gabriel Ange

Que san[s] dilation

Dieu envoya sur terre

Par grant compation

3. - Or, nous dites, Marie

Que vous dit Gabriel

Quand vous porta nouvelle

Du vrai Dieu éternel?

- Dieu soit ô toi, Marie

Dit-il sans fiction

Tu es de grâce emplie

Et bénédiction.

4. - Or, nous dites, Marie

Où étiez-vous alors

1. Nouel ha melody, dre guir devotion,

Canamp de gloar Marië hemp

Entre en ol merhet

e voy choezet $h$...

De vam de Roui er bet

rac ... a uoui.

2. Leueret dign, Marie,

piuë vouy e ... s(o) ...

A consas duh quentanf

a douere

"An ail voui Gabriel,

ganet Roui en ...

A des ar er bet-man

dré sin a ca

3. Leueret dimp ...

$\ldots$ as ......... el

Pe consas .......

........ eternel

Mari

En .... en ........ et.

7. Leueret dimp, Marië, ma h-oue(h)-hui d-en er 
Quand Gabriel Archange

Vous fist un tel rapport?

- J'étois en Galilée

Plaisante région

En ma chambre enfermée

En contemplation

5. - Or, nous dites, Marie

Cet ange Gabriel

Vous dit il autre chose

En ce salut nouve[[]?

- Tu concevras, Marie

Dit-il sans fiction

Fils de Dieu, je t'affie

Et sans corruption

6. - Or, nous dites, Marie

En présence de tous

A ces douces paroles

Que répondîtes-vous?

- Comment pourrait se faire

Par telle mention

Le Fils de Dieu, mon père

Prenne incarnation.

7. - Or, nous dites, Marie

Que vous dit Gabriel

Quand vous vit esbahie

De ce salut nouvel?

- Marie ne te soucie

C'est l'obombration

Du Saint-Esprit, ma mie

Et l'oppération.
Ma vezau saludet

guet en el Gabriel?

"En Galile e h-ouen

en contemplation,

E cambrë hac e study

hemp mui dilation."

4. Leueret dimp, Marië

en el-ze zo hanuet,

Pe laras-enf dih-uy,

mait e h-oueuh beniguet?

"Conseu hep mar a ry,

ha hem corruption,

Vr map ...s prenou

d-un dro ol hon enenueu."

5. Leuer dimp, Marië,

na uezauh-ui souhet?

Na pe responzauh-hui

d-er conseu lauaret?

"Penaus, et respondis,

e arriuezé en dra-zé?

Biscoueh doh nep vnan

compaigneh ne-n boué."

6. Leueret dimp, Marië,

pe laras duh en ail

...... d-oueh disconfortet

dré er salut Nouel?

"... hum confort, Marië,

ne hum soucie[t] quet,

... Doué, Roui en Ellet, zo inouh disquennet." 